\title{
An Increase of Abdominal Pressure Increases Pulmonary Edema in Oleic Acid-induced Lung Injury
}

\author{
Michael Quintel, Paolo Pelosi, Pietro Caironi, Jurgen Peter Meinhardt, Thomas Luecke, Peter Herrmann, \\ Paolo Taccone, Christian Rylander, Franco Valenza, Eleonora Carlesso, and Luciano Gattinoni
}

Institut für Anästhesiologie und Operative Intensivmedizin, Universitätsklinikum Mannheim, Mannheim, Germany; Department of Clinical and Biological Sciences, Universita' degli Studi dell'Insubria, Ospedale di Circolo, Fondazione Macchi, Varese; Istituto di Anestesia e Rianimazione, Universita' degli Studi di Milano, Ospedale Policlinico IRCCS, Milano, Italy; and Department of Medical Sciences, Clinical Physiology, Uppsala University Hospital, Uppsala, Sweden

\begin{abstract}
Increased abdominal pressure is common in intensive care unit patients. To investigate its impact on respiration and hemodynamics we applied intraabdominal pressure (alAP) of 0 and $20 \mathrm{~cm} \mathrm{H}_{2} \mathrm{O}$ (pneumoperitoneum) in seven pigs. The whole-lung computed tomography scan and a complete set of respiratory and hemodynamics variables were recorded both in healthy lung and after oleic acid (OA) injury. In healthy lung, alAP $20 \mathrm{~cm} \mathrm{H}_{2} \mathrm{O}$ significantly lowered the gas content, leaving the tissue content unchanged. In $\mathrm{OA}$ injured lung at alAP $0 \mathrm{~cm} \mathrm{H}_{2} \mathrm{O}$, the gas content significantly decreased compared with healthy lung. The excess tissue mass (edema) amounted to $30 \pm 24 \%$ of the original tissue weight (455 \pm $80 \mathrm{~g}$ ). The edema was primarily distributed in the base regions and was not gravity dependent. Heart volume, central venous, pulmonary artery, wedge, and systemic arterial pressures significantly increased. At alAP $20 \mathrm{~cm} \mathrm{H}_{2} \mathrm{O}$ in OA-injured lung, the central venous and pulmonary artery pressures further increased. The gas content further decreased, and the excess tissue mass rose up to $103 \pm 37 \%$ (tissue weight $905 \pm 134 \mathrm{~g}$ ), with homogeneous distribution along the cephalocaudal and sternovertebral axis. We conclude that in OAinjured lung, the increase of IAP increases the amount of edema.
\end{abstract}

Keywords: intraabdominal pressure; acute respiratory distress syndrome; pulmonary edema; lung mechanics; computed tomography scan

The importance of intraabdominal pressure (IAP) in acute lung injury and acute respiratory distress syndrome has been recently suggested (1). For a long time any change in respiratory mechanics in patients with acute lung injury/acute respiratory distress syndrome was attributed to lung mechanics, whereas chest wall mechanics was assumed to be normal. However, few studies in which chest wall elastance was actually measured have showed that it was abnormal in a substantial proportion of patients with acute lung injury/acute respiratory distress syndrome (2-4). We (5) and others (6) have described different chest wall mechanics in patients with pulmonary and extrapulmonary acute respiratory distress syndrome, mainly due to different IAP values.

However, apart from respiratory mechanics, the increased intrathoracic pressure caused by chest wall impairment may have important consequences on hemodynamics (7). We investigated the effect of changing IAP during controlled mechanical ventilation in healthy and diseased lungs. Surprisingly, the increase of IAP had an unexpected impact on lung edema, likely related to its formation and clearance. We wish to report our findings and

(Received in original form September 17, 2002; accepted in final form December 5, 2003) Correspondence and requests for reprints should be addressed to Luciano Gattinoni, M.D., F.R.C.P., Istituto di Anestesia e Rianimazione, Ospedale Maggiore PoliclinicoIRCCS, Via Francesco Sforza 35, 20122 Milan, Italy. E-mail: gattinon@policlinico.mi.it

This article has an online supplement, which is accessible from this issue's table of contents online at www.atsjournals.org

Am J Respir Crit Care Med Vol 169. pp 534-541, 2004

Originally Published in Press as DOI: 10.1164/rccm.200209-1060OC on December 11, 2003 Internet address: www.atsjournals.org to discuss the underlying mechanisms and the possible clinical implications.

\section{METHODS}

(Additional details about Methods are provided in an online supplement.)

The study group consisted of seven anesthetized and paralyzed domestic pigs $(41 \pm 4 \mathrm{~kg})$ ventilated throughout the experiment in supine position, with a VT of $12 \mathrm{ml} / \mathrm{kg}$, respiratory rate of 12-14 breaths/minute, positive end-expiratory pressure of $5 \mathrm{~cm} \mathrm{H}_{2} \mathrm{O}$, and $\mathrm{FI}_{\mathrm{O}_{2}}$ of 1.0. The animals were fully instrumented for hemodynamic monitoring (carotid artery, right atrium, mean pulmonary artery pressures $[\overline{\mathrm{Ppa}}]$, and thermodilution Q). Distal tracheal, esophageal, and gastric pressures were all measured.

The pressure-volume curves of the total respiratory system, lung, and chest wall were measured by stepwise inflation (supersyringe, 100 $\mathrm{ml} \mathrm{step)} \mathrm{up} \mathrm{to} 1,500 \mathrm{ml}$ or to a maximum static pressure of $45 \mathrm{~cm} \mathrm{H}_{2} \mathrm{O}$, after normalization for lung history (45 $\mathrm{cm} \mathrm{H}_{2} \mathrm{O}, 15$ seconds) (8).

\section{Lung Imaging and Image Analysis}

The entire lungs were imaged with computed tomography (CT) scan from apex to base. The cross-sectional images of the lungs were initially processed using the image analysis software package MagicView (Siemens, Elema, Sweden), then manually contoured by eye, and finally analyzed with a custom-made program (graphical software Lab-View; National Instruments, Austin, TX). The frequency distribution of the Hounsfield attenuation of each voxel (volume $1.84 \mathrm{~mm}^{3}$ ) was computed ranging from $-1,000$ to +200 Hounsfield units. Then, we computed the gas and tissue volume of the whole lung and the amount of overinflated ( -1000 to -900 Hounsfield units), normally ( -900 to -500 Hounsfield units), poorly ( -500 to -100 Hounsfield units), and nonaerated $(-100$ to +200 Hounsfield units) lung tissue (8). The gas and tissue distribution along the cephalocaudal (10 equal intervals) and sternovertebral axis (4 equal levels) was also computed. The excess tissue mass, as an estimate of lung edema (9), was computed as the difference between the actual tissue mass and the tissue mass measured in healthy lung with normal abdominal pressure, expressed as a percentage of the normal tissue mass in healthy lung with normal abdominal pressure. The right and left lungs were separately analyzed.

\section{Experimental Protocol}

The animals were studied in four conditions in which a complete set of hemodynamics, respiratory mechanics, gas exchange, and whole CT scan at end-expiration $\left(0 \mathrm{~cm} \mathrm{H}_{2} \mathrm{O}\right)$ were collected according to the following sequence: (1) baseline in healthy lung, with an applied intraabdominal pressure (aIAP) of $0 \mathrm{~cm} \mathrm{H}_{2} \mathrm{O}$. Measurements were taken 30 minutes after instrumentation of the animal. (2) A pneumoperitoneum was induced by an air insufflator, with aIAP set at $20 \mathrm{~cm} \mathrm{H}_{2} \mathrm{O}$, and measurements were taken 30 minutes later. (3) The pneumoperitoneum was then eliminated (aIAP $0 \mathrm{~cm} \mathrm{H}_{2} \mathrm{O}$ ), and lung injury was induced by injection of oleic acid in the right atrium $(0.15 \mathrm{ml} / \mathrm{kg}$ in $20 \mathrm{ml}$ of saline). After about 90 minutes, in the presence of a stable lung injury, measurements were taken. (4) The pneumoperitoneum was then induced again (aIAP $20 \mathrm{~cm} \mathrm{H}_{2} \mathrm{O}$ ), and measurements were taken about 15 minutes thereafter.

\section{Time Course of Oleic Acid-induced Edema Formation}

Five additional animals $(30 \pm 5 \mathrm{~kg})$ were studied, after the injection of oleic acid, over a period of 150 minutes (oleic acid time course group). 
To investigate the edema formation and its distribution, a CT scan of the entire lungs was taken after about 30,70, and 150 minutes from the injection of oleic acid without any change in the abdominal pressure.

\section{Statistical Analysis}

All data are expressed as mean \pm SD. In the study group, the effects of oleic acid injury and aIAP, as well as the difference in regional distribution, were tested with two-way repeated measures analysis of variance. In the oleic acid time course group the progression of the injury and its cephalocaudal distribution over time were analyzed, respectively, with one-way and two-way repeated measures analysis of variance. In case of significant results, a post hoc multiple comparison analysis was performed using Bonferroni's correction. Statistical significance was accepted as $\mathrm{p}$ values less than 0.05 .

\section{RESULTS}

Representative images of the four experimental conditions, healthy and oleic acid-injured lung, with and without increase of aIAP are shown in Figure 1.

\section{Healthy Lungs}

Gas/tissue volumes. As shown in Table 1, at aIAP of $20 \mathrm{~cm} \mathrm{H}_{2} \mathrm{O}$ the total lung volume was significantly lower than at aIAP of 0 $\mathrm{cm} \mathrm{H}_{2} \mathrm{O}$ due to the reduction of gas volume (the left and right lungs behaved similarly), the tissue volume being unchanged. The amount of nonaerated tissue increased, from $13 \pm 8 \%$ of the tissue mass at aIAP of $0 \mathrm{~cm} \mathrm{H}_{2} \mathrm{O}$ to $23 \pm 11 \%$ at aIAP of $20 \mathrm{~cm} \mathrm{H}_{2} \mathrm{O}$, even though not significantly $(\mathrm{p}=0.422)$.

Mechanics. As shown in Table 2, at aIAP of $20 \mathrm{~cm} \mathrm{H}_{2} \mathrm{O}$ the gastric pressure was significantly higher than at aIAP of $0 \mathrm{~cm}$ $\mathrm{H}_{2} \mathrm{O}$, whereas the esophageal pressure at end-expiration was unchanged. At aIAP of $20 \mathrm{~cm} \mathrm{H}_{2} \mathrm{O}$, the increase in elastance of the total respiratory system at $100 \mathrm{ml}$ lung inflation was only due to the increased elastance of the chest wall, whereas, at $500 \mathrm{ml}$ lung inflation, part of the increase was due to the lung component.
Hemodynamics. The hemodynamic changes between aIAP of $0 \mathrm{~cm} \mathrm{H}_{2} \mathrm{O}$ and $20 \mathrm{~cm} \mathrm{H}_{2} \mathrm{O}$ are reported in Table 3. Q was unchanged in its stroke volume and frequency, but $\overline{\mathrm{Ppa}}$, central venous (Pcv), mean arterial, and occlusion pressures significantly increased. The heart volume also increased significantly (11 \pm $19 \%$ ) increasing the aIAP (Table 1).

Gas exchange. Arterial and mixed venous blood gases are reported in Table 4. The increase in aIAP mainly led to a significant decrease in $\mathrm{Pa}_{\mathrm{O}_{2}}$.

\section{Oleic Acid-injured Lungs}

Gas/tissue volumes. As shown in Table 1, the total lung volume was significantly lower than the normal lung with the same aIAP of $0 \mathrm{~cm} \mathrm{H} \mathrm{H}_{2} \mathrm{O}(19 \pm 18 \%$ decrease $)$. This reduction derived from a decrease in gas volume greater than the increase in tissue volume, the "excess tissue" probably being lung edema. On raise of aIAP to $20 \mathrm{~cm} \mathrm{H}_{2} \mathrm{O}$, the tissue volume almost doubled and the excess tissue mass increased from $30 \pm 24 \%$ at aIAP of 0 $\mathrm{cm} \mathrm{H}_{2} \mathrm{O}$ to $103 \pm 37 \%(\mathrm{p}<0.001)$.

Mechanics. As shown in Table 2, gastric and esophageal pressures at end-expiration significantly increased from aIAP of 0 to $20 \mathrm{~cm} \mathrm{H}_{2} \mathrm{O}$, as did the elastance of the respiratory system, mainly in its lung component. At aIAP of $0 \mathrm{~cm} \mathrm{H}_{2} \mathrm{O}$ the elastance increase was essentially due to the lung component, and at aIAP of $20 \mathrm{~cm} \mathrm{H}_{2} \mathrm{O}$, the further increase was caused both by the lung and chest wall components.

Hemodynamics. At aIAP of $0 \mathrm{~cm} \mathrm{H}_{2} \mathrm{O}$ the Q did not change significantly, but $\overline{\mathrm{Ppa}}$, systemic arterial pressure, and heart volume significantly increased compared with aIAP of $0 \mathrm{~cm} \mathrm{H}_{2} \mathrm{O}$ in healthy lungs. A further significant increase in $\overline{\mathrm{Ppa}}$ and Pcv was observed when aIAP was raised to $20 \mathrm{~cm} \mathrm{H}_{2} \mathrm{O}$ (Table 3).

Gas exchange. The gas exchange in oleic acid-injured lungs was greatly impaired compared with healthy lungs, and it further deteriorated on increasing aIAP to $20 \mathrm{~cm} \mathrm{H}_{2} \mathrm{O}$ (Table 4).

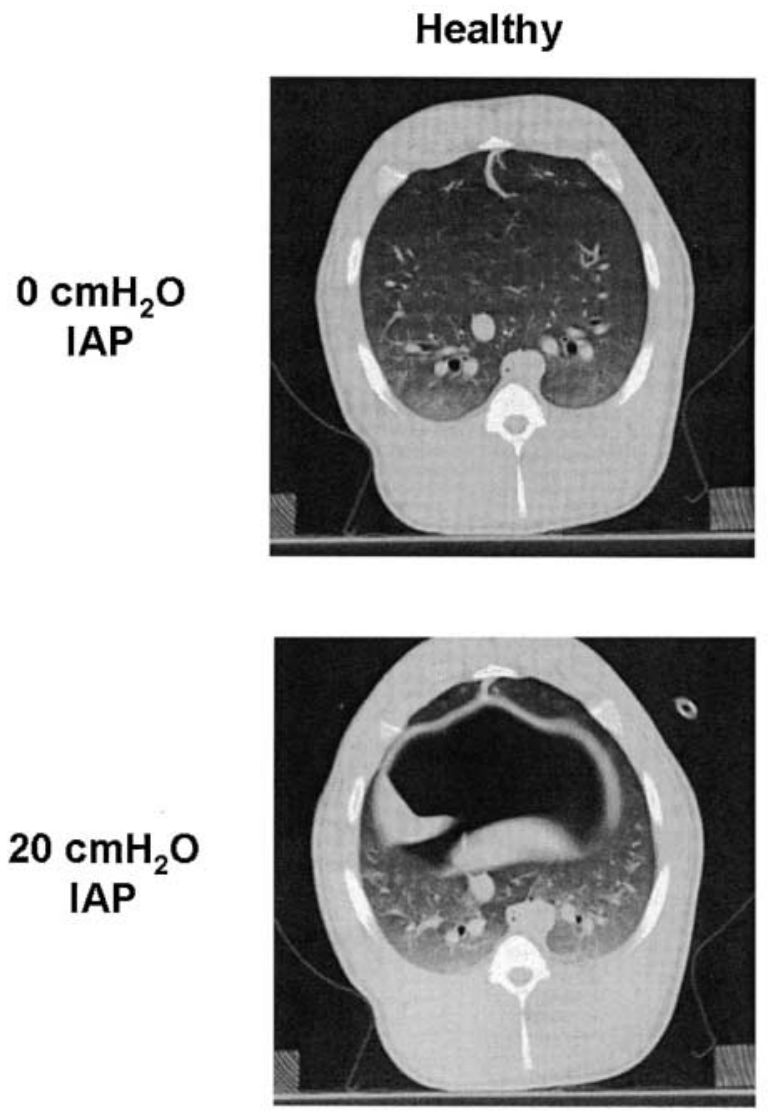

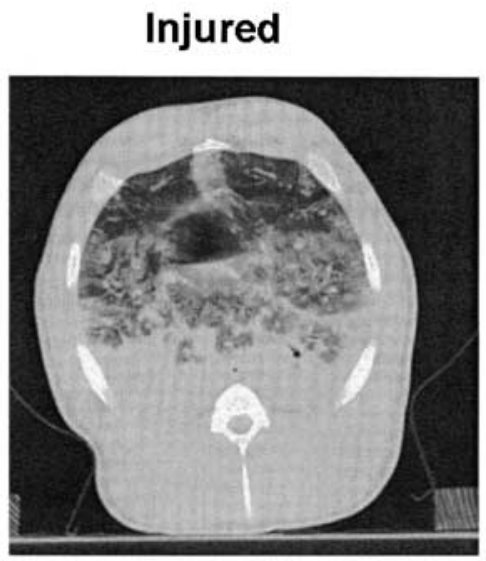

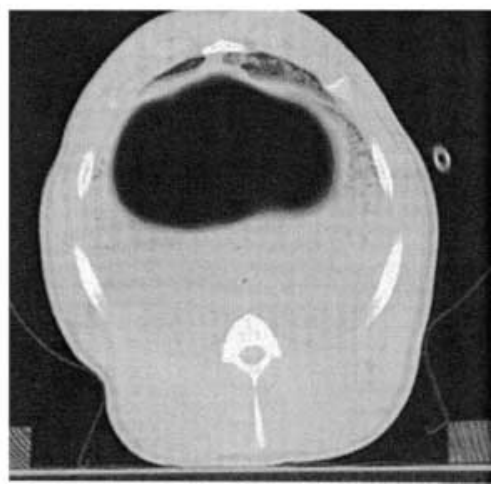

Figure 1. Computed tomography $(C T)$ images of healthy lung at applied intraabdominal pressure (alAP) of 0 and $20 \mathrm{~cm}$ $\mathrm{H}_{2} \mathrm{O}$ (upper and lower left images, respectively), and CT images of oleic acid-injured lung at alAP of 0 and $20 \mathrm{~cm} \mathrm{H}$ (upper and lower right images, respectively). 
TABLE 1. THORACIC VOLUMES AND LENGTHS

\begin{tabular}{|c|c|c|c|c|}
\hline & \multicolumn{2}{|c|}{ Healthy } & \multicolumn{2}{|c|}{ Injured } \\
\hline & alAP 0 & alAP 20 & alAP 0 & alAP 20 \\
\hline Total volume, $\mathrm{ml}$ & $1,244.7 \pm 371.2$ & $820.9^{\ddagger} \pm 387.8$ & $958.3^{\S} \pm 189.9$ & $1,077.8^{\S} \pm 77.5$ \\
\hline Left lung, ml & $678.9^{\dagger} \pm 214.0$ & $470.7^{\dagger \ddagger} \pm 80.4$ & $529.2^{\dagger \S} \pm 103.7$ & $590.6^{\dagger \S} \pm 42.9$ \\
\hline Right lung, ml & $565.8 \pm 160.3$ & $350.2^{\ddagger} \pm 72.8$ & $429.1^{\S} \pm 90.2$ & $487.3^{\S} \pm 37.0$ \\
\hline Gas volume, $\mathrm{ml}$ & $790.2 \pm 303.5$ & $395.2^{\ddagger} \pm 142.1$ & $367.0^{\S} \pm 147.6$ & $167.0^{\ddagger \S} \pm 111.6$ \\
\hline Left lung, ml & $429.1^{\dagger} \pm 172.5$ & $232.3^{\dagger \neq} \pm 75.1$ & $204.8^{\dagger} \pm 84.1$ & $93.5^{\dagger \ddagger \S} \pm 65.6$ \\
\hline Right lung, ml & $361.1 \pm 133.6$ & $162.8^{\ddagger} \pm 69.6$ & $162.2^{\S} \pm 64.6$ & $73.4^{\ddagger} \pm 46.3$ \\
\hline Tissue mass, $\mathrm{g}$ & $454.7 \pm 79.9$ & $425.4 \pm 54.5$ & $588.2^{\S} \pm 119.6$ & $905.3^{\text {本}} \pm 134.1$ \\
\hline Left lung, g & $249.9^{\dagger} \pm 47.9$ & $237.9^{\dagger} \pm 35.7$ & $322.3^{\dagger \S} \pm 59.3$ & $494.1^{\dagger \neq \S} \pm 73.3$ \\
\hline Right lung, $\mathrm{g}$ & $204.9 \pm 32.8$ & $187.5 \pm 21.2$ & $265.9^{\S} \pm 62.2$ & $411.1^{\ddagger \S} \pm 61.9$ \\
\hline Hyperinflated tissue, $\mathrm{g}$ & $0.9 \pm 0.8$ & $0.6 \pm 0.8$ & $0.2 \pm 0.0$ & $0.1 \pm 0.3$ \\
\hline Normally aerated tissue, $\mathrm{g}$ & $282.0 \pm 100.8$ & $149.0^{\ddagger} \pm 46.0$ & $140.5^{\S} \pm 60.1$ & $43.8^{\ddagger \S} \pm 37.3$ \\
\hline Poorly aerated tissue, $\mathrm{g}$ & $116.4 \pm 20.9$ & $174.9 \pm 41.8$ & $210.0^{\S} \pm 36.2$ & $229.1 \pm 97.1$ \\
\hline Nonaerated tissue, $\mathrm{g}$ & $55.4 \pm 29.1$ & $101.0 \pm 49.7$ & $237.5^{\S} \pm 124.6$ & $632.2^{\ddagger \S} \pm 243.9$ \\
\hline Length, ${ }^{*} \mathrm{~cm}$ & $23.7 \pm 2.38$ & $20.4^{\ddagger} \pm 0.8$ & $21.4^{\S} \pm 1.6$ & $21.8 \pm 0.8$ \\
\hline Heart volume, $\mathrm{ml}$ & $453.6 \pm 71.7$ & $503.2^{\ddagger} \pm 93.4$ & $525.8^{\S} \pm 44.4$ & $531.9 \pm 54.0$ \\
\hline Mediastinal volume, $\mathrm{ml}$ & $86.5 \pm 16.7$ & $88.7 \pm 16.7$ & $98.0 \pm 26.2$ & $101.0 \pm 29.1$ \\
\hline Total thoracic volume, $\mathrm{ml}$ & $1,784.8 \pm 325.7$ & $1,412.8^{\ddagger} \pm 114.3$ & $1,582.1^{\S} \pm 199.2$ & $1,710.8^{\S} \pm 97.1$ \\
\hline
\end{tabular}

Definition of abbreviations: alAP = applied intraabdominal pressure; mediastinal volume $=$ volume of the mediastinal space without heart volume; total volume = total lung volume (gas + tissue).

Data are expressed as mean \pm SD

* Lung length refers to 14 lungs (7 right and 7 left).

$\dagger p<0.05$ vs. right lung at the same pulmonary status and alAP.

${ }^{\ddagger} \mathrm{p}<0.05$ vs. alAP $0 \mathrm{~cm} \mathrm{H} \mathrm{H}_{2}$ at the same pulmonary status (injured/healthy).

$\S p<0.05$ vs. healthy lung at the same alAP.

\section{Regional Distribution of Gas/Tissue Volumes in Healthy and Injured Lungs}

Healthy lung. As shown in Figure 2 (left panel), the total amount of lung tissue was similar at aIAP of 0 and $20 \mathrm{~cm} \mathrm{H}_{2} \mathrm{O}$. Its regional distribution was slightly different along the cephalocaudal axis, most likely due to the lung distortion and shortening at higher aIAP (see Table 1). At $20 \mathrm{~cm} \mathrm{H}_{2} \mathrm{O}$ of aIAP, total gas volume dropped, and the gas content in each interval was approximately halved. A similar effect was observed along the sternovertebral axis (data not shown).

Oleic acid-injured lung. As shown in Figure 2 (right panel), the tissue content was significantly higher at aIAP of $20 \mathrm{~cm} \mathrm{H}_{2} \mathrm{O}$ than at $0 \mathrm{~cm} \mathrm{H}_{2} \mathrm{O}$, and this increase was mainly concentrated between intervals 1 and 7 . The same pattern was observed along the sternovertebral axis (data not shown). The gas content was significantly lower at aIAP $20 \mathrm{~cm} \mathrm{H}_{2} \mathrm{O}$ than at $0 \mathrm{~cm} \mathrm{H}_{2} \mathrm{O}$. The distribution of the excess tissue mass along the cephalocaudal axis is reported in Figure 3. At aIAP of $0 \mathrm{~cm} \mathrm{H}_{2} \mathrm{O}$ there was no edema in the apical intervals, but it progressively increased from hilum to bases. Increasing the aIAP to $20 \mathrm{~cm} \mathrm{H}_{2} \mathrm{O}$ caused a uniform distribution of the edema along the entire cephalocaudal axis. The vertical distribution of the excess tissue mass in oleic acid-injured animals, at apex, hilum, and bases is reported in Figure 4. At aIAP of $0 \mathrm{~cm} \mathrm{H}_{2} \mathrm{O}$, the edema was present only at the bases, and it did not appear to be dependent on gravity as it was uniformly distributed from nondependent to dependent lung levels. The same nongravitational distribution was observed at aIAP of $20 \mathrm{~cm} \mathrm{H}_{2} \mathrm{O}$, where the apex, hilum, and bases regions were equally involved.

TABLE 2. RESPIRATORY MECHANICS

\begin{tabular}{|c|c|c|c|c|}
\hline & \multicolumn{2}{|c|}{ Healthy } & \multicolumn{2}{|c|}{ Injured } \\
\hline & alAP 0 & alAP 20 & alAP 0 & alAP 20 \\
\hline $\mathrm{Pga}, \mathrm{cm} \mathrm{H} \mathrm{H}_{2} \mathrm{O}$ & $2.7 \pm 2.38$ & $15.8^{*} \pm 5.6$ & $4.6 \pm 1.32$ & $17.0^{*} \pm 4.5$ \\
\hline Pes, $\mathrm{cm} \mathrm{H}_{2} \mathrm{O}$ & $3.4 \pm 3.4$ & $2.7 \pm 5.8$ & $4.6 \pm 4.5$ & $9.4^{\dagger} \pm 5.3$ \\
\hline Est $_{\mathrm{rs}}, 100 \mathrm{~cm} \mathrm{H}_{2} \mathrm{O} / \mathrm{L}$ & $27.7 \pm 7.7$ & $71.0^{*} \pm 10.6$ & $101.3^{\dagger} \pm 49.2$ & $178.7^{* \dagger} \pm 50.8$ \\
\hline Est $_{\mathrm{cw}}, 100 \mathrm{~cm} \mathrm{H}_{2} \mathrm{O} / \mathrm{L}$ & $6.7 \pm 71.4$ & $46.4^{*} \pm 18.3$ & $11.0 \pm 7.9$ & $33.1^{*^{\dagger}} \pm 21.7$ \\
\hline $\mathrm{Est}_{1}, 100 \mathrm{~cm} \mathrm{H} \mathrm{H}_{2} \mathrm{O} / \mathrm{L}$ & $21.0 \pm 8.7$ & $24.5 \pm 11.9$ & $90.3^{\dagger} \pm 50.8$ & $145.7^{* \dagger} \pm 59.0$ \\
\hline Est $_{\mathrm{rs}}, 500 \mathrm{~cm} \mathrm{H}_{2} \mathrm{O} / \mathrm{L}$ & $18.4 \pm 2.9$ & $49.8^{*} \pm 8.7$ & $41.7^{\dagger} \pm 10.1$ & $69.7^{\star^{\dagger}} \pm 13.5$ \\
\hline $\mathrm{Est}_{\mathrm{cW}}, 500 \mathrm{~cm} \mathrm{H}_{2} \mathrm{O} / \mathrm{L}$ & $6.4 \pm 4.8$ & $32.2^{*} \pm 15.3$ & $6.8 \pm 2.6$ & $22.9^{\star \dagger} \pm 10.8$ \\
\hline $\mathrm{Est}_{1}, 500 \mathrm{~cm} \mathrm{H}{ }_{2} \mathrm{O} / \mathrm{L}$ & $12.0 \pm 5.0$ & $17.6^{*} \pm 9.3$ & $34.9^{\dagger} \pm 10.1$ & $46.9^{* \dagger} \pm 11.9$ \\
\hline
\end{tabular}

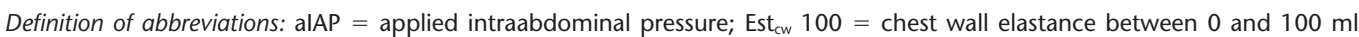
lung inflation of the pressure-volume curve; Est $_{\mathrm{cw}} 500$ = chest wall elastance between 0 and $500 \mathrm{ml}$ lung inflation of the pressure-volume curve; Est $100=$ lung elastance between 0 and $100 \mathrm{ml}$ lung inflation of the pressure-volume curve; Est $500=$ lung elastance between 0 and $500 \mathrm{ml}$ lung inflation of the pressure-volume curve; Est $\mathrm{rs}_{\mathrm{rs}} 100=$ elastance of the respiratory system between 0 and $100 \mathrm{ml}$ lung inflation of the pressure-volume curve; Est $500=$ elastance of the respiratory system between 0 and $500 \mathrm{ml}$ lung inflation of the pressure-volume curve; PEEP = positive end-expiratory pressure; Pes = esophageal pressure at end-expiration ( $0 \mathrm{~cm} \mathrm{H}_{2} \mathrm{O}$ PEEP); Pga = gastric pressure at end-expiration $\left(0 \mathrm{~cm} \mathrm{H}_{2} \mathrm{O}\right.$ PEEP).

Data are expressed as mean $\pm \mathrm{SD}$.

${ }^{*} \mathrm{p}<0.05$ vs. alAP $0 \mathrm{~cm} \mathrm{H} \mathrm{H}_{2}$ at the same pulmonary status (healthy/injured).

${ }^{\dagger} \mathrm{p}<0.05$ vs. healthy lung at the same alAP. 
TABLE 3. HEMODYNAMICS

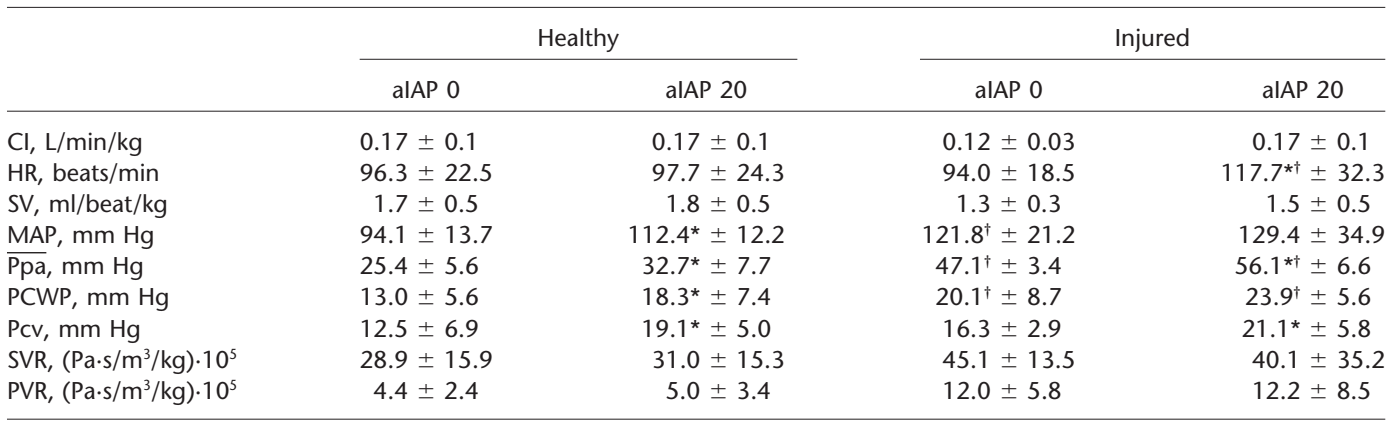

Definition of abbreviations: alAP = applied intraabdominal pressure; $\mathrm{Cl}=$ cardiac index; $\mathrm{HR}=$ heart rate; MAP = mean arterial pressure; $\mathrm{PCV}=$ central venous pressure; $\mathrm{PCWP}=$ pulmonary closing wedge pressure; $\overline{\mathrm{Ppa}}=$ mean pulmonary artery pressure; $\mathrm{PVR}=$ pulmonary vascular resistance; $\mathrm{SV}=$ stroke volume; SVR = systemic vascular resistance.

Data are expressed as mean \pm SD.

* $\mathrm{p}<0.05$ vs. alAP $0 \mathrm{~cm} \mathrm{H}$ O at the same pulmonary status (injured/healthy).

${ }^{\dagger} p<0.05$ vs. healthy lung at the same alAP.

\section{Time Course of Oleic Acid-induced Edema Formation}

To investigate a possible time effect on edema formation, in five additional experiments (oleic acid time course group), the natural course of the oleic acid-induced lung edema and its distribution were sequentially studied over a period of $150 \mathrm{~min}$ utes, maintaining the aIAP at $0 \mathrm{~cm} \mathrm{H}_{2} \mathrm{O}$. The net edema formation rate, as a function of time, is reported in Figure 5, left panel, whereas its cephalocaudal distribution, at different experimental times, is reported in the right panel. As shown, the edema formation decreased exponentially with time (time constant: 34.7 minutes), and between 91 and 108 minutes (i.e., the time in which aIAP was increased in the study group), the edema formation rate was almost negligible $(1.3 \mathrm{ml} /$ minute at 91 minutes and 0.8 $\mathrm{ml} /$ minute at 108 minutes vs. $20 \mathrm{ml} /$ minute after increasing aIAP in the study group). The total excess tissue mass measured at $34 \pm 4,74 \pm 4$, and $159 \pm 5$ minutes was, respectively, $44 \pm 15$, $62 \pm 16$, and $65 \pm 15 \%$. Indeed, the excess tissue mass was stable between 74 and 159 minutes $(p=0.502)$, whereas it was significantly lower at 34 minutes $(\mathrm{p}<0.001$, two-way repeated measures analysis of variance). Its cephalocaudal distribution at 34, 74, and 159 minutes was similar to what we found in the study group at 91 minutes before the increase of aIAP ( $\mathrm{p}=$ 0.999, two-way analysis of variance, see Figures 3 and 5, right panel, for comparison).

\section{DISCUSSION}

\section{Healthy Lungs}

Applying aIAP of $20 \mathrm{~cm} \mathrm{H}_{2} \mathrm{O}$ by abdominal gas insufflation induced an increase of gastric pressure and displacement of diaphragm. The length of the lung decreased from $23.7 \pm 2.4$ to $20.4 \pm 0.8 \mathrm{~cm}$, and the total gas volume decreased from $790 \pm 304$ to $395 \pm 143 \mathrm{ml}$, suggesting lung collapse. It seems surprising at first sight that the esophageal pressure at endexpiration was unchanged between aIAP of 0 and aIAP of 20 $\mathrm{cm} \mathrm{H}_{2} \mathrm{O}$. However, these measurements were taken at end-expiration with the respiratory system open to the atmosphere, and the lungs were normal. In these conditions, the increased gastric pressure moves the diaphragm upward, reducing the thoracic volume and the gas content, and there is no reason why the pleural pressure, in static conditions, should change. In contrast, during inflation with either 100 or $500 \mathrm{ml}$ (closed system at aIAP of $20 \mathrm{~cm} \mathrm{H}_{2} \mathrm{O}$ ) the pleural pressure significantly increased due to a greater stiffness of the chest wall and diaphragm.

On raising the aIAP to $20 \mathrm{~cm} \mathrm{H}_{2} \mathrm{O}, \overline{\mathrm{Ppa}}, \mathrm{Pcv}$, mean arterial, and occlusion pressures all increased, with an increase in heart volume and no change in $\dot{Q}$ (frequency and stroke volume). These findings are consistent both with experimental $(10,11)$ and clinical data (12-14) during laparoscopy associated with pneumoperitoneum. Most of these studies reported increases of mean arterial pressure and $\overline{\mathrm{Ppa}}$ and an enlargement of the right and left heart sections as seen by transesophageal echocardiogra-

TABLE 4. GAS EXCHANGE

\begin{tabular}{|c|c|c|c|c|}
\hline & \multicolumn{2}{|c|}{ Healthy } & \multicolumn{2}{|c|}{ Injured } \\
\hline & alAP 0 & alAP 20 & alAP 0 & alAP 20 \\
\hline $\mathrm{Pa}_{\mathrm{O}_{2}}, \mathrm{~mm} \mathrm{Hg}$ & $468.6 \pm 58.5$ & $405.8^{*} \pm 82.0$ & $96.9^{\dagger} \pm 33.1$ & $43.1^{* \dagger} \pm 12.4$ \\
\hline $\mathrm{Pa}_{\mathrm{CO}_{2}}, \mathrm{~mm} \mathrm{Hg}$ & $45.9 \pm 12.2$ & $50.0 \pm 13.8$ & $50.5 \pm 9.0$ & $74.1^{* \dagger} \pm 2.9$ \\
\hline $\mathrm{pHa}$ & $7.37 \pm 0.1$ & $7.34 \pm 0.1$ & $7.31^{\dagger} \pm 0.1$ & $7.20^{\star \dagger} \pm 0.1$ \\
\hline $\mathrm{Sa}_{\mathrm{O}_{2}} \%$ & $100.0 \pm 0.0$ & $100.0 \pm 0.0$ & $95.5 \pm 4.5$ & $58.7^{\star \dagger} \pm 18.5$ \\
\hline $\mathrm{Pv}_{\mathrm{O} 2}, \mathrm{~mm} \mathrm{Hg}$ & $72.0 \pm 14.8$ & $75.7 \pm 15.3$ & $46.1^{\dagger} \pm 8.7$ & $32.1^{\star \dagger} \pm 8.2$ \\
\hline $\mathrm{P} \overline{\mathrm{v}}_{\mathrm{CO}_{2}}, \mathrm{~mm} \mathrm{Hg}$ & $50.3 \pm 14.6$ & $53.5 \pm 12.7$ & $52.7 \pm 11.9$ & $76.0^{\star \dagger} \pm 4.8$ \\
\hline $\mathrm{pHv}$ & $7.34 \pm 0.1$ & $7.29 \pm 0.1$ & $7.30 \pm 0.1$ & $7.16^{\star \dagger} \pm 0.1$ \\
\hline $\mathrm{Sv}_{\mathrm{O} 2}, \%$ & $94.1 \pm 4.5$ & $94.3 \pm 4.8$ & $71.7^{\dagger} \pm 11.9$ & $38.3^{* \dagger} \pm 14.8$ \\
\hline Q̇s/Q்T & $0.23 \pm 0.1$ & $0.32 \pm 0.1$ & $0.44^{\dagger} \pm 0.2$ & $0.71^{* \dagger} \pm 0.2$ \\
\hline
\end{tabular}

Definition of abbreviations: alAP = applied intraabdominal pressure; $\mathrm{pHa}=$ arterial $\mathrm{pH} ; \mathrm{pHv}=$ venous $\mathrm{pH}$; $\mathrm{Pv}_{\mathrm{O}_{2}}=\mathrm{oxygen}$ venous partial pressure; $\mathrm{Sv}_{\mathrm{O}_{2}}=$ oxygen venous saturation.

Data are expressed as mean \pm SD.

${ }^{*} \mathrm{p}<0.05$ vs. alAP $0 \mathrm{~cm} \mathrm{H} \mathrm{O}_{2}$ at the same pulmonary status (injured/healthy).

${ }^{\dagger} \mathrm{p}<0.05$ vs. healthy lung at the same alAP. 
Healthy lung

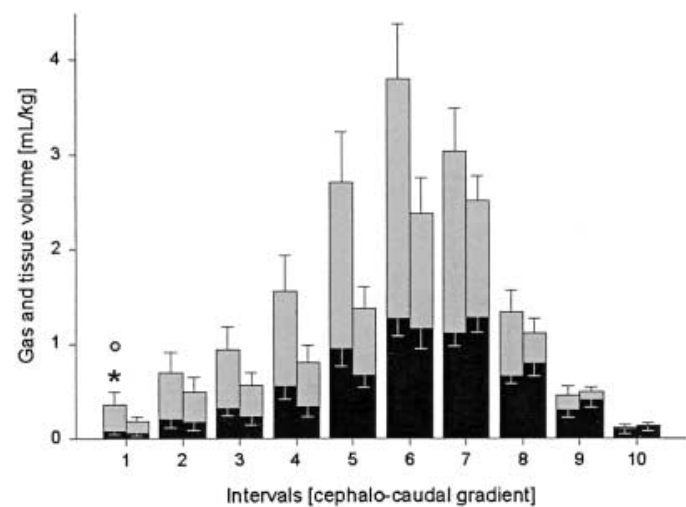

Injured lung

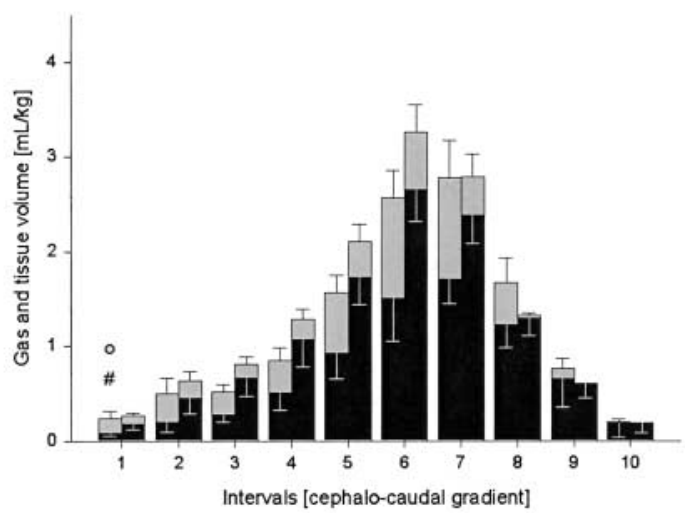

Figure 2. Regional distribution of gas (gray bars) and tissue (solid bars) volumes along the cephalocaudal axis, both in healthy (left panel) and in injured lungs (right panel). For each interval, the left columns refer to alAP $0 \mathrm{~cm} \mathrm{H}_{2} \mathrm{O}$ and the right columns refer to alAP 20 $\mathrm{cm} \mathrm{H}_{2} \mathrm{O}$. Each value is the mean of 14 lungs (7 right and 7 left). Data are expressed as mean \pm SD. * $p$ Values less than 0.001, two-way repeated measures analysis of variance (ANOVA) for tissue volume; factor: intervals and interaction ( IIAP $\times$ intervals). ${ }^{\circ} \mathrm{p}$ Values less than 0.001 , two-way repeated measures ANOVA for gas volume; factors: alAP, intervals, and interaction (alAP $\times$ intervals). $\mathrm{p}$ Values less than 0.001 , two-way repeated measures ANOVA for tissue volume; factors: alAP, intervals, and interaction (alAP $\times$ intervals). phy $(15,16)$. The modifications of hemodynamics are generally considered a consequence of an increase in intrathoracic blood volume, caused by a shift from the compressible abdomen to the uncompressed thorax. Other explanations include a central nervous system-mediated response due to impaired venous drainage from the central nervous system (17).

\section{Oleic Acid-injured Lung}

After the induction of the injury, at aIAP of $0 \mathrm{~cm} \mathrm{H}_{2} \mathrm{O}$, the edema amounted to $30 \pm 24 \%$ and was located in the basal regions. As the time interval between oleic acid injection and measurement of edema by CT scan was $91 \pm 7$ minutes, the net increase of lung edema averaged $1.5 \pm 1.1 \mathrm{ml} / \mathrm{minute}$. This value corresponds to the same order of magnitude recently described in dogs studied with a similar protocol (18). Similarly, in the oleic acid time course group the edema formation rate decreased exponentially after injury (time constant: 34.7 minutes) and averaged $1.3 \mathrm{ml} / \mathrm{minute}$ at 91 minutes (range 1.1-1.8 $\mathrm{ml} / \mathrm{minute}$ ) (Figure 5, left panel).

Despite the edema formation, the total lung volume significantly decreased in comparison with healthy lung at IAP of 0 $\mathrm{cm} \mathrm{H}_{2} \mathrm{O}$, suggesting that the increase in lung excess tissue mass did not fully compensate the reduction in gas space. This indicates lung collapse, as previously reported in patients with acute lung injury (19). The edema, however, was unevenly distributed along the cephalocaudal axis because it was present only in the basal regions. Here, however, it was distributed homogeneously along the sternovertebral axis.

The edema distribution along the cephalocaudal axis seems to follow the regional blood flow distribution recently described in pigs (20). The fractional blood flow related to the fractional weight of the longitudinal slices increases from apex to bases, reflecting either the capillary density or diameter per unit of tissue. The nongravitational distribution of edema, as observed in this study, has been found both in patients (21) and in animal models $(22,23)$. Therefore, it is possible that at first the edema increases according to the flow distribution. Then, the increased lung edema, through an increase in lung weight and superim- posed pressure $(24,25)$, may cause collapse of the dependent regions and divert the flow to the upper regions (26), ending up with a nongravitational distribution.

$\overline{\mathrm{Ppa}}$, mean arterial, and occlusion pressures increased after the induction of oleic acid injury. Although the rise in $\overline{\mathrm{Ppa}}$ has been already described in different experimental settings (27$29)$, the increase in mean arterial and occlusion pressures has not been previously reported (30). We could not completely exclude a possible influence of the instrumental apparatus used for the pneumoperitoneum induction on hemodynamics. Nevertheless, its impact on the edema formation, if any, is questionable because the excess tissue mass recorded under these conditions was similar or even smaller than previously reported $(29,31)$.

The most striking and unexpected finding of this investigation was that applying aIAP of $20 \mathrm{~cm} \mathrm{H}_{2} \mathrm{O}$ after oleic acid-induced lung injury resulted in a more than twofold increase of excess

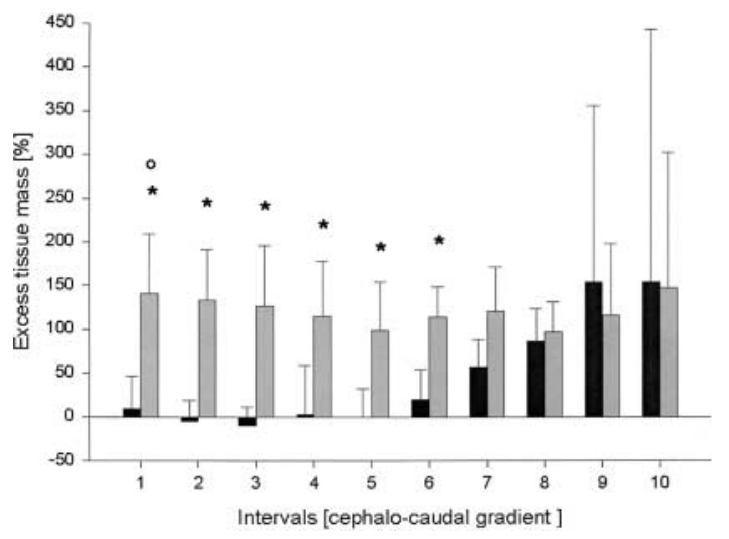

Figure 3. Regional distribution of excess tissue mass along the cephalocaudal axis (injured lung). Each value is the mean of 14 lungs (7 right and 7 left). Data are expressed as mean \pm SD. ${ }^{*} p$ Values less than 0.001 versus alAP $0 \mathrm{~cm} \mathrm{H}_{2} \mathrm{O}$ at the same level. ${ }^{\circ} \mathrm{p}$ Values less than 0.001 , twoway repeated measures ANOVA; factor: alAP, and interaction (aIAP $\times$

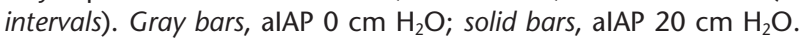



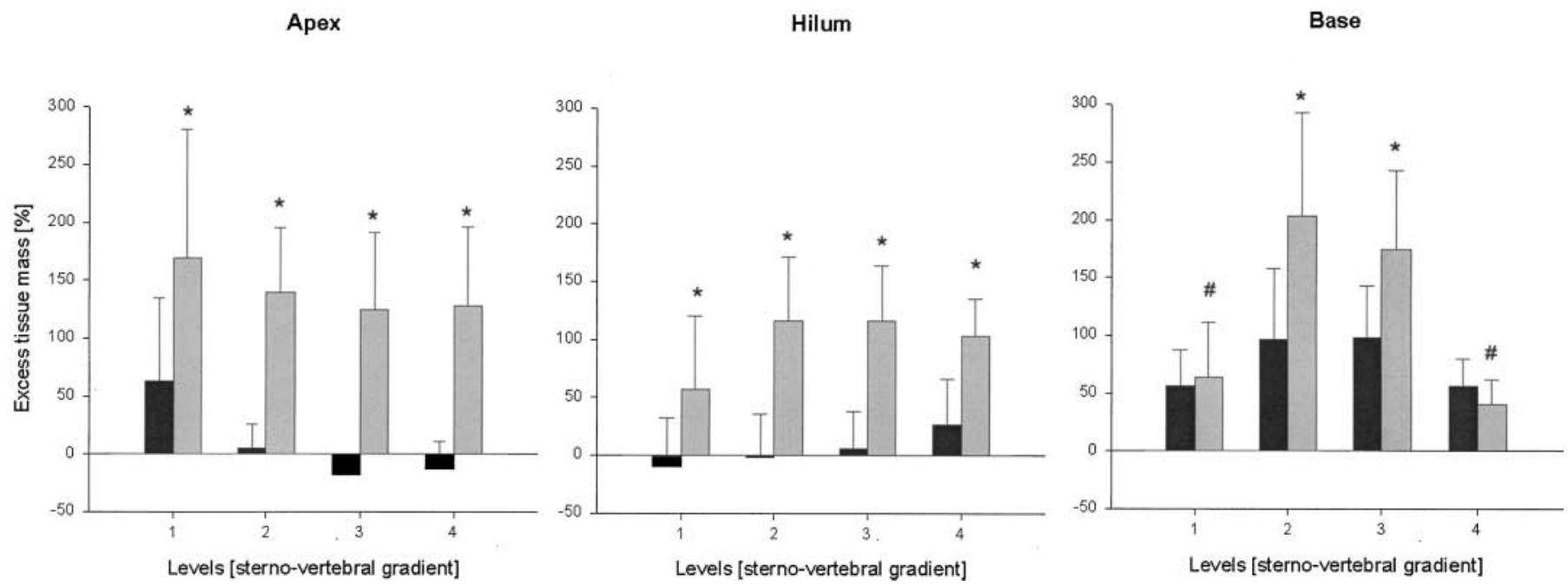

Figure 4. Regional distribution of excess tissue mass along the sternovertebral axis (injured lung), at lung apex (left panel), hilum (middle panel), and base (right panel) (see Methods). Each value is the mean of 14 lungs (7 right and 7 left). Data are expressed as mean \pm SD. ${ }^{*} p$ Values less than 0.001 versus alAP $0 \mathrm{~cm} \mathrm{H}_{2} \mathrm{O}$ at the same level. ${ }^{\circ} \mathrm{p}$ Values less than 0.05 versus Level 1 at the same alAP. ${ }^{\#} \mathrm{p}$ Values less than 0.001 versus Levels 2 and 3 at the same alAP. Solid bars, alAP $0 \mathrm{~cm} \mathrm{H}_{2} \mathrm{O}$; gray bars, alAP $20 \mathrm{~cm} \mathrm{H}_{2} \mathrm{O}$.

tissue mass (from $30 \pm 24$ to $103 \pm 37 \%$ ). Moreover, the edema formation involved the whole lung, with homogenous distribution along both the cephalocaudal and the sternovertebral axes. As the time lag between the application of aIAP of $20 \mathrm{~cm} \mathrm{H}_{2} \mathrm{O}$ and the measurement of the excess tissue mass by $\mathrm{CT}$ scan averaged $17 \pm 8$ minutes, the net fluid accumulation averaged $20.0 \pm 9.3 \mathrm{ml} / \mathrm{minute}$

Before discussing the mechanisms underlying these findings and the possible clinical implications, two major issues must be addressed. First, whether the excess tissue mass we measured represents true edema or not, and second, the possible time effect of oleic acid injury on the increased tissue mass recorded after raising aIAP.

The increase in excess tissue mass may be due both to an increased lung edema and to an increase of pulmonary blood volume. Unfortunately, the CT cannot discriminate between them. Reportedly, increasing aIAP to the range of 15 to 17 $\mathrm{cm} \mathrm{H}_{2} \mathrm{O}$ in humans resulted in increased (14) or unmodified intrathoracic blood volume $(32,33)$. In experiments on eight healthy pigs performed in Milan (F. Valenza, unpublished observations) in which the blood shift was measured (PiCCO; Pulsion Medical System, Munich, Germany), we found that increasing aIAP to $13 \mathrm{~cm} \mathrm{H}_{2} \mathrm{O}$ caused a significant increase in intrathoracic blood volume from $18.1 \pm 1.6$ to $22.4 \pm 2.9 \mathrm{ml} / \mathrm{kg}(\mathrm{p}=0.023)$. A further increase of aIAP to $26 \mathrm{~cm} \mathrm{H}_{2} \mathrm{O}$ reduced the intrathoracic blood volume to $17.9 \pm 2.2 \mathrm{ml} / \mathrm{kg}$. In our study group increasing aIAP to $20 \mathrm{~cm} \mathrm{H}_{2} \mathrm{O}$ in healthy lung did not cause any change in tissue mass (see Table 1), suggesting a lack of blood shift. From all these data and considering that the pulmonary blood volume represents about $30 \%$ of the intrathoracic blood volume (34), the blood shift may account for an increased tissue mass in the study group ranging only from 0 to 40 to $50 \mathrm{ml}$ (compared with the $317 \mathrm{ml}$ increase recorded after aIAP of $\left.20 \mathrm{~cm} \mathrm{H}_{2} \mathrm{O}\right)$.

A second issue to be addressed is the possible time effect
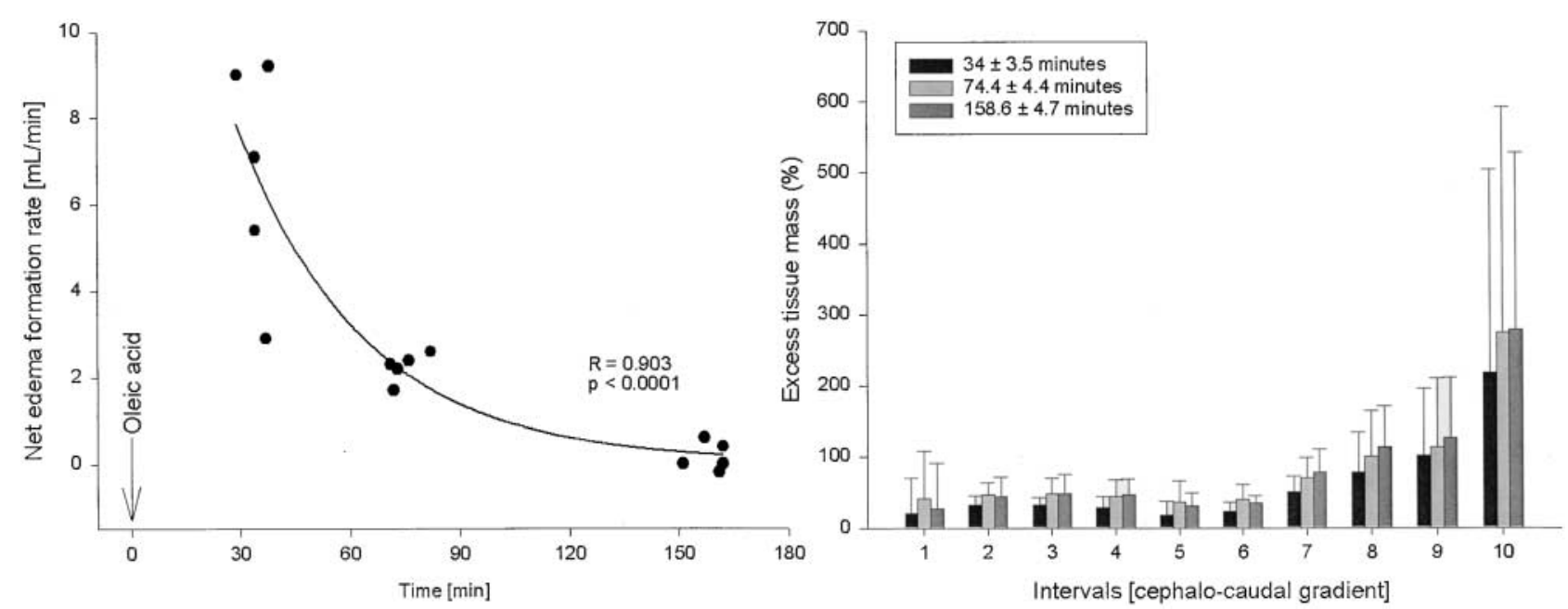

Figure 5. (Left panel) Edema formation rate as a function of time. The amount of edema produced over time was computed as the difference between the lung tissue weight computed after oleic acid injection and the lung tissue weight at baseline. The time scale represents the time intervals

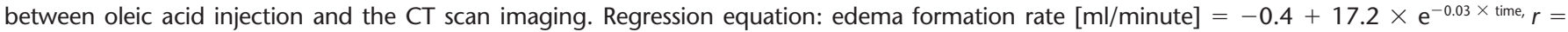
0.91, $p$ values less than 0.001. (Right panel) Cephalocaudal distribution of excess tissue mass computed $34 \pm 4,74 \pm 4$, and $159 \pm 5$ minutes after oleic acid injection. Data are expressed as mean \pm SD. 
on lung edema formation. In the study group, we decided to investigate the aIAP effect at about 90 minutes after the oleic acid injection because at this time the oleic acid edema reaches the plateau (35-42). However, after we observed the fast and dramatic increase of lung edema when raising aIAP, we performed another set of experiments to clearly define, in our own experimental setting, the natural course of oleic acid edema without any change of aIAP. As the CT scan used to investigate the study group (in Mannheim) was no longer available, the five additional experiments were performed in Uppsala (C.R. and P.H.). The overall results clearly confirm that between approximately 70 and 150 minutes the oleic acid edema is stable (see Figure 5). Indeed, during the time frame in which we increased aIAP in the study group (from 91 to 108 minutes), the net edema formation computed in the oleic acid time course group was almost negligible (average $0.2 \pm 0.3 \mathrm{ml} /$ minute), whereas in the study group, after aIAP increase, it averaged $20 \pm 9.3 \mathrm{ml} /$ minute. Moreover, the regional distribution of lung edema recorded in the additional experiments was similar to the one we measured in the study group before increasing aIAP. Finally, the total amount of excess tissue mass after aIAP increase in the study group was significantly greater than the excess tissue mass we measured in the additional experiments either at 74 or $158 \mathrm{~min}$ utes $(\mathrm{p}<0.001$, one-way analysis of variance).

Taken together, all these data strongly suggest that the increase of excess tissue mass after increasing IAP in this oleic acid model is primarily lung edema and that the time effect is negligible.

We were not able to find any report of this unexpected association between IAP rise and increase of lung edema, and our interpretation can only be speculative, although the basic physiology may provide the background for a possible explanation.

Edema is a dynamic phenomenon and its amount is the net result of the forces favoring its formation and the mechanisms favoring its clearance $(43,44)$. Increasing the aIAP to $20 \mathrm{~cm}$ $\mathrm{H}_{2} \mathrm{O}$ caused a significant rise in Pcv and $\overline{\mathrm{Ppa}}$, with no change in $\dot{Q}$, whereas the capillary occlusion pressure tended to rise, although not significantly.

It is well known that high Pcv (45), $\overline{\mathrm{Ppa}}(46,47)$, and pulmonary capillary pressure (48) may all favor edema formation in lungs with altered permeability. Indeed, the hemodynamic alteration induced by an increased aIAP in a leaking lung may justify the increase in lung edema, and likely represents the main explanation of our findings, considering also the short time in which the phenomenon was observed.

However, the increase of aIAP not only may favor lung edema formation, but, likely, may also impair its clearance. In fact, the clearance of lung edema can take three possible routes: the lymphatic pathways, the reabsorption through the pulmonary capillaries when the interstitial pressure exceeds the capillary pressure, and the pleural capillaries, leading to pleural effusion $(49,50)$. All these pathways have a final common route to clear the edema, i.e., the thoracic veins, which are subjected to the intrathoracic pressure. At aIAP of $20 \mathrm{~cm} \mathrm{H}_{2} \mathrm{O}$, the esophageal pressure we recorded was three times the baseline, very likely due to the increase in lung weight (25). The effects of an increase in intrathoracic pressure on lymphatic flow were described a decade ago $(51,52)$. In animal models, raising intrathoracic pressure reduced the lymphatic flow and impaired the clearance of lung edema (53-55). In our study, we found a positive correlation between the increase of esophageal pressure (i.e., the pleural pressure) and the edema formation rate after aIAP of $20 \mathrm{~cm}$ $\mathrm{H}_{2} \mathrm{O}$ (edema formation rate $[\mathrm{ml} /$ minute $]=1.7 \times \Delta$ esophageal pressure $+7.0, r=0.83, \mathrm{p}<0.05$, data not shown). It is thus possible that the increase in lung edema we observed at aIAP of $20 \mathrm{~cm} \mathrm{H} \mathrm{H}_{2} \mathrm{O}$ was the result of two combined phenomena, i.e., increased edema formation and decreased clearance.

\section{Clinical Consequences}

The results obtained in animal models, often tested in extreme conditions, cannot be generalized to patients. However, if at least part of these findings and their underlying mechanisms are transferable to patients, the clinical consequences may be substantial. First, the levels of IAP we applied in this study are relatively common in critically ill patients. In fact, about $30 \%$ of consecutive critically ill patients show an abnormal increase in IAP (56). The IAP has to be measured directly, as it has been shown that the clinical assessment alone has poor sensitivity and specificity to detect an increase (57). Several procedures in critically ill patients may increase the IAP and its effects, such as the heavy sedation, causing bowel hypomobility and partial loss of diaphragmatic tone. In case of acute lung injury/acute respiratory distress syndrome - if our findings on pigs are transferable to humans - any increase in IAP would potentially be dangerous, not only reducing, as already known, the gas content of an already diseased lung, but also potentially inducing an increase of pulmonary edema. Although these findings need to be proved in humans, we believe that the measurement of IAP and careful attention to avoid procedures that may raise it would already be worthwhile.

Conflict of Interest Statement: M.Q. has no declared conflict of interest; P.P. has no declared conflict of interest; P.C. has no declared conflict of interest; I.P.M. has no declared conflict of interest; T.L. has no declared conflict of interest; P.H. has no declared conflict of interest; P.T. has no declared conflict of interest; C.R. has no declared conflict of interest; F.V. has no declared conflict of interest; E.C. has no declared conflict of interest; L.G. has no declared conflict of interest.

Acknowledgment: The authors thank Dr. Angelo Colombo for his revision and advice in the statistical analysis.

\section{References}

1. Malbrain ML. Abdominal pressure in the critically ill: measurement and clinical relevance. Intensive Care Med 1999;25:1453-1458.

2. Katz JA, Zinn SE, Ozanne GM, Fairley HB. Pulmonary, chest wall, and lung-thorax elastances in acute respiratory failure. Chest 1981;80:304311.

3. Jardin F, Genevray B, Brun-Ney D, Bourdarias JP. Influence of lung and chest wall compliances on transmission of airway pressure to the pleural space in critically ill patients. Chest 1985;88:653-658.

4. Pelosi P, Cereda M, Foti G, Giacomini M, Pesenti A. Alterations of lung and chest wall mechanics in patients with acute lung injury: effects of positive end-expiratory pressure. Am J Respir Crit Care Med 1995;152: 531-537.

5. Gattinoni L, Pelosi P, Suter PM, Pedoto A, Vercesi P, Lissoni A. Acute respiratory distress syndrome caused by pulmonary and extrapulmonary disease: different syndromes? Am J Respir Crit Care Med 1998; 158:3-11.

6. Ranieri VM, Brienza N, Santostasi S, Puntillo F, Mascia L, Vitale N, Giuliani R, Memeo V, Bruno F, Flore $\mathrm{T}$, et al. Impairment of lung and chest wall mechanics in patients with acute respiratory distress syndrome: role of abdominal distension. Am J Respir Crit Care Med 1997;156:1082-1091.

7. Pinsky MR. Heart-lung interactions. In: Marini JJ, editor. Physiological basis of ventilatory support. New York: Marcel Dekker; 1998 p. 491-518.

8. Gattinoni L, Pesenti A, Avalli L, Rossi F, Bombino M. Pressure-volume curve of total respiratory system in acute respiratory failure: computed tomographic scan study. Am Rev Respir Dis 1987;136:730-736.

9. Gattinoni L, Pesenti A, Bombino M, Baglioni S, Rivolta M, Rossi F, Rossi G, Fumagalli R, Marcolin R, Mascheroni D, et al. Relationships between lung computed tomographic density, gas exchange, and PEEP in acute respiratory failure. Anesthesiology 1988;69:824-832.

10. Bannenberg JJ, Rademaker BM, Froeling FM, Meijer DW. Hemodynamics during laparoscopic extra- and intraperitoneal insufflation: an experimental study. Surg Endosc 1997;11:911-914.

11. Kaklamanos IG, Condos S, Merrell RC. Time-related changes in hemodynamic parameters and pressure-derived indices of left ventricular function in a porcine model of prolonged pneumoperitoneum. Surg Endosc 2000;14:834-838.

12. Hirvonen EA, Nuutinen LS, Kauko M. Hemodynamic changes due to 
Trendelenburg positioning and pneumoperitoneum during laparoscopic hysterectomy. Acta Anaesthesiol Scand 1995;39:949-955.

13. Andersson L, Wallin CJ, Sollevi A, Odeberg-Wernerman S. Pneumoperitoneum in healthy humans does not affect central blood volume or cardiac output. Acta Anaesthesiol Scand 1999;43:809-814.

14. Hofer CK, Zalunardo MP, Klaghofer R, Spahr T, Pasch T, Zollinger A. Changes in intrathoracic blood volume associated with pneumoperitoneum and positioning. Acta Anaesthesiol Scand 2002;46:303-308.

15. Branche PE, Duperret SL, Sagnard PE, Boulez JL, Petit PL, Viale JP. Left ventricular loading modifications induced by pneumoperitoneum: a time course echocardiographic study. Anesth Analg 1998;86:482-487.

16. Gentili A, Iannettone CM, Pigna A, Landuzzi V, Lima M, Baroncini S. Cardiocirculatory changes during videolaparoscopy in children: an echocardiographic study. Paediatr Anaesth 2000;10:399-406.

17. Ben-Haim M, Mandeli J, Friedman RL, Rosenthal RJ. Mechanisms of systemic hypertension during acute elevation of intraabdominal pressure. J Surg Res 2000;91:101-105.

18. Caruthers SD, Paschal CB, Pou NA, Roselli RJ, Harris TR. Regional measurements of pulmonary edema by using magnetic resonance imaging. J Appl Physiol 1998;84:2143-2153.

19. Puybasset L, Cluzel P, Chao N, Slutsky AS, Coriat P, Rouby JJ. A computed tomography scan assessment of regional lung volume in acute lung injury: The CT Scan ARDS Study Group. Am J Respir Crit Care Med 1998;158:1644-1655.

20. Morris KP, Cox PN, Mazer CD, Frndova H, McKerlie C, Wolfe R. Distribution of pulmonary blood flow in the perfluorocarbon-filled lung. Intensive Care Med 2000;26:756-763.

21. Pelosi P, D'Andrea L, Vitale G, Pesenti A, Gattinoni L. Vertical gradient of regional lung inflation in adult respiratory distress syndrome. Am J Respir Crit Care Med 1994;149:8-13.

22. Jones T, Jones HA, Rhodes CG, Buckingham PD, Hughes JM. Distribution of extravascular fluid volumes in isolated perfused lungs measured with H215O. J Clin Invest 1976;57:706-713.

23. Hales CA, Kanarek DJ, Ahluwalia B, Latty A, Erdmann J, Javahori S, Kazemi H. Regional edema formation in isolated perfused dog lungs. Circ Res 1981;48:121-127.

24. Gattinoni L, D'Andrea L, Pelosi P, Vitale G, Pesenti A, Fumagalli R. Regional effects and mechanism of positive end-expiratory pressure in early adult respiratory distress syndrome. JAMA 1993;269:2122-2127.

25. Pelosi P, Goldner M, McKibben A, Adams A, Eccher G, Caironi P, Losappio S, Gattinoni L, Marini JJ. Recruitment and derecruitment during acute respiratory failure: an experimental study. Am J Respir Crit Care Med 2001;164:122-130.

26. Schuster DP, Haller J. A quantitative correlation of extravascular lung water accumulation with vascular permeability and hydrostatic pressure measurements: a positron emission tomography study. J Crit Care 2002:5:161-168.

27. Richard JC, Janier M, Lavenne F, Berthier V, Lebars D, Annat G, Decailliot F, Guerin C. Effect of position, nitric oxide, and almitrine on lung perfusion in a porcine model of acute lung injury. $J$ Appl Physiol 2002;93:2181-2191.

28. Bleyl JU, Ragaller M, Tschö U, Regner M, Hübler M, Kanzow M, Vincent $\mathrm{O}$, Albrecht M. Changes in pulmonary function and oxygenation during application of perfluorocarbon vapor in healthy and oleic acidinjured animals. Crit Care Med 2002;30:1340-1347.

29. Wrigge H, Zinserling J, Neumann P, Defosse J, Magnusson A, Putensen C, Hedenstierna G. Spontaneous breathing improves lung aeration in oleic acid-induced lung injury. Anesthesiology 2003;99:376-384.

30. Schuster DP. ARDS: clinical lessons from oleic acid model of acute lung injury. Am J Respir Crit Care Med 1994;149:245-260.

31. Scillia P, Kafi SA, Melot C, Keyzer C, Naeije R, Gevenois PA. Oleic acid-induced lung injury: thin-section CT evaluation in dogs. Radiology 2001;219:724-731.

32. Anderson L, Wallin C-J, Sollevi A, Odeberg-Wernerman S. Pneumoperitoneum in healthy humans does not affect central blood volume or cardiac output. Acta Anaesthesiol Scand 1999;43:809-814.

33. Hachenberg T, Ebel C, Czorny M, Thomas H, Wendt M. Intrathoracic and pulmonary blood volume during $\mathrm{CO} 2$-pneumoperitoneum in humans. Acta Anaesthesiol Scand 1998;42:794-798.

34. Fishman AP. Pulmonary circulation. In: Fishman AP, editor. Handbook of physiology, section 3: the respiratory system, Volume 1: circulation and nonrespiratory function. Philadelphia: American Physiological Society; 1985 . p. 93-165.

35. Slutsky RA, Long S, Peck WW, Higgins CB, Mattrey R. Pulmonary density distribution in experimental noncardiac canine pulmonary edema evaluated by computed transmission tomography. Invest Radiol 1984:19:168-173.

36. Schuster DP, Trulock EP. Correlation of changes in oxygenation, lung water and hemodynamics after oleic acid-induced acute lung injury in dogs. Crit Care Med 1984;12:1044-1048.

37. Sum-Ping ST, Symreng T, Jebson P, Kamal GD. Stable and reproducible porcine model of acute lung injury induced by oleic acid. Crit Care Med 1991;19:405-408.

38. Rosenthal C, Caronia C, Quinn C, Lugo N, Sagy M. A comparison among animal models of acute lung injury. Crit Care Med 1998;26:912-916.

39. Scillia P, Kafi SA, Melot C, Keyzer C, Naeije R, Gevenois PA. Oleic acid-induced lung injury: thin-section CT evaluation in dogs. Radiology 2001:219:724-731.

40. Schuster DP, Haller J. Effect of body position on regional pulmonary blood flow during acute pulmonary edema in dogs: a positron emission tomography study. J Crit Care 2002;6:19-28.

41. Hedlund L, Effman E, Bates W, Beck J, Goulding P, Putnam CE. Pulmonary edema: a CT study of regional changes in lung density following oleic acid injury. J Comput Assist Tomogr 2002;6:939-946.

42. Schuster DP, Anderson C, Kozlowski J, Lange N. Regional pulmonary perfusion in patients with acute pulmonary edema. J Nucl Med 2002; 43:863-870.

43. Sznajder JI. Alveolar edema must be cleared for the acute respiratory distress syndrome patient to survive. Am J Respir Crit Care Med 2001; 163:1293-1294.

44. Ware LB, Matthay MA. Alveolar fluid clearance is impaired in the majority of patients with acute lung injury and the acute respiratory distress syndrome. Am J Respir Crit Care Med 2001;163:1376-1383.

45. Allen SJ, Drake RE, Katz J, Gabel JC, Laine GA. Elevation of superior vena caval pressure increases extravascular lung water after endotoxemia. J Appl Physiol 1987;62:1006-1009.

46. Minnear FL, Barie PS, Malik AB. Effects of transient pulmonary hypertension on pulmonary vascular permeability. J Appl Physiol 1983;55: 983-989.

47. Gattinoni L, Pesenti A, Bombino M, Baglioni S, Rivolta M, Rossi F, Rossi G, Fumagalli R, Marcolin R, Mascheroni D, et al. Relationship between lung computer tomographic density, gas exchange, and PEEP in acute respiratory failure. Anesthesiology 1988;69:824-832.

48. Gabel JC, Hansen TN, Drake RE. Effect of endotoxin on lung fluid balance in unanesthetized sheep. J Appl Physiol 1984;56:489-494.

49. Taylor AE, Parker JC. Pulmonary interstitial spaces and lymphatics. In: Fishman AP, editor. Handbook of physiology, section 3: the respiratory system, Volume 1: circulation and nonrespiratory function. Mobile, AL: American Physiological Society; 1985. p. 169-230.

50. Frostell CG. Lung lymph drainage. Acta Anaesthesiol Scand Suppl 1991; 95:55-57.

51. Blomqvist H, Berg B, Frostell C, Wickerts CJ, Hedenstierna G. Net fluid leakage (LN) in experimental pulmonary oedema in the dog. Acta Anaesthesiol Scand 1990;34:377-383.

52. Blomqvist H, Berg B, Frostell C, Wickerts CJ, Hedenstierna G. Thoracic lymph drainage in the dog: evaluation of a new model. Intensive Care Med 1991;17:45-51

53. Laine GA, Allen SJ, Katz J, Gabel JC, Drake RE. Effects of systemic venous pressure elevation on lymph flow and lung edema formation. J Appl Physiol 1986;61:1634-1638.

54. Frostell CG, Blomqvist H, Hedenstierna G, Halbig I, Pieper R. Thoracic and abdominal lymph drainage in relation to mechanical ventilation and PEEP. Acta Anaesthesiol Scand 1987;31:405-412.

55. Blomqvist H, Wickerts CJ, Berg B, Frostell C, Jolin A, Hedenstierna G. Does PEEP facilitate the resolution of extravascular lung water after experimental hydrostatic pulmonary oedema? Eur Respir J 1991;4: 1053-1059.

56. Malbrain ML. Intra-abdominal pressure in the intensive care unit: clinical tool or toy? In: Vincent JL, editor. Yearbook of intensive care and emergency medicine. Berlin: Springer Verlag; 2001. p. 547-585.

57. Kirkpatrick AW, Brenneman FD, McLean RF, Rapanos T, Boulanger BR. Is clinical examination an accurate indicator of raised intra-abdominal pressure in critically injured patients? Can J Surg 2000;43:207-211. 